\title{
ANALIZA MOŻLIWOŚCI WYKORZYSTANIA OGNIWA PALIWOWEGO SOFC JAKO POMOCNICZEJ JEDNOSTKI MOCY APU DLA WSPÓŁCZESNEGO SAMOLOTU PASAŻERSKIEGO
}

\begin{abstract}
Współczesne samoloty pasażerskie należą do czołówki najbardziej niezawodnych i bezpiecznych środków transportu publicznego. Samoloty te certyfikowane są m.in. normą ETOPS (Extended range Twin Operations) zezwalającą dwusilnikowym samolotom pasażerskim operować na trasach długodystansowych, wcześniej niedostępnych dla maszyn o takiej liczbie silników. Norma ETOPS wymaga jednak zastosowania na pokładzie dwusilnikowego samolotu pasażerskiego dodatkowych, awaryjnych źródeł zasilania energią elektryczną, pneumatyczną i hydrauliczną, kompensujących (częściowo) spadek wydajności pokładowych systemów energetycznych przy niesprawności jednego z silników i systemów z nimi powiązanych. W artykule przeprowadzono analizę wykorzystania różnych typów ogniw paliwowych w technice lotniczej oraz przedstawiono projekt wstępny pomocniczej jednostki mocy APU, wykorzystującej ogniwo paliwowe SOFC (Solid Oxide Fuel Cell), przeznaczonej dla (awaryjnego) zasilania energią elektryczną samolotu pasażerskiego w koncepcji „More Electric Aircraft”.
\end{abstract}

Słowa kluczowe: samolot pasażerski, pomocnicza jednostka mocy, More Electric Aircraft, ogniwo paliwowe, SOFC - Solid Oxide Fuel Cell

\section{Wstęp}

Współczesny samolot pasażerski stanowi przykład jednego z najbardziej zaawansowanych wytworów myśli ludzkiej. Dynamiczny rozwój technologiczny obejmujący m.in. lotnicze zespoły napędowe oraz pokładowe źródła energii elektrycznej, umożliwił budowę i wprowadzenie na trasy długodystansowe dwusilnikowych samolotów pasażerskich. Niesprawność jednego silnika dla dwusilnikowego samolotu pasażerskiego to nie tylko ograniczenie czy też niesymetria ciągu a także spadek mocy generowanej przez źródła energii elektrycznej, pneumatycznej czy też hydraulicznej [1]. Na początku lat $50 \mathrm{XX}$ w. do

\footnotetext{
1 Autor do korespondencji/corresponding author: Adam Jaroszewicz, Politechnika Wrocławska, 50-370 Wrocław: Wybrzeże Wyspiańskiego 27, tel.: 7132044 52, e-mail: adam.jaroszewicz@pwr.edu.pl
} 
lotnictwa pasażerskiego dla dwusilnikowych samolotów pasażerskich z napędem odrzutowym (m.in. De Havilland Comet, Boeing 707) wprowadzono tzw. „zasadę 60 minut” [11]. Zasada ta wymagała od przewoźników lotniczych takiego planowania trasy przelotu samolotu pasażerskiego pomiędzy lotniskami docelowymi, aby trasa ta nie była oddalona bardziej niż 60 minut lotu od najbliższego lotniska, dającego możliwość bezpiecznego lądowania w sytuacjach awaryjnych. Zasada ta przerodziła się w latach $80 \mathrm{XX}$ w. w normę, która funkcjonuje do dziś w nieco zmienionej formie, zwana normą (certyfikatem) ETOPS (Rys. 1).

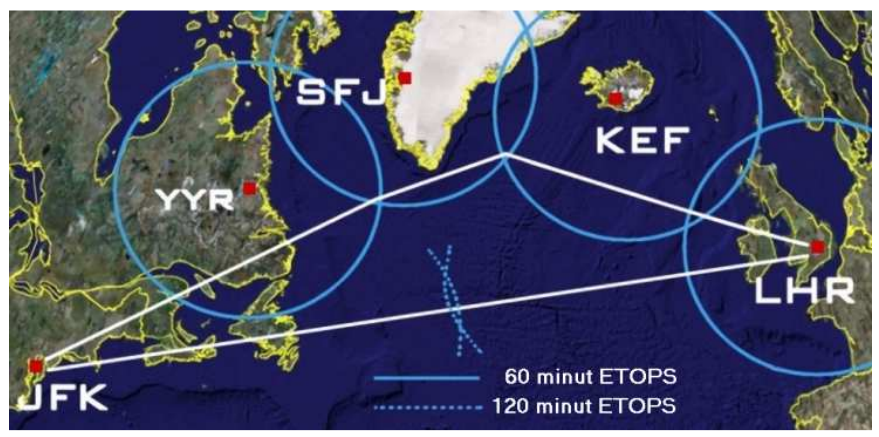

Rys. 1. Trasa lotu samolotów pasażerskich pomiędzy lotniskami JFK a LHR dla samolotów: z ETOPS 60 / ETOPS 120

Fig. 1. Air route of passenger aicrafts between JFK and LHR airports for aircrafts with ETOPS 60 / ETOPS 120

Norma ETOPS wymaga zastosowania na pokładzie dwusilnikowego samolotu pasażerskiego dodatkowych, awaryjnych źródeł zasilania energią elektryczną, pneumatyczną i hydrauliczną, kompensujących (częściowo) spadek wydajności pokładowych systemów energetycznych przy niesprawności jednego z silników i systemów z nimi powiązanych. Współcześnie na pokładach samolotów pasażerskich budowanych w technologii „,konwencjonalnej” jak i „More Electric Aircraft" wykorzystywane są m.in.: pomocnicze jednostki mocy APU (Auxiliary Power Unit) (energia elektryczna/hydrauliczna/pneumatyczna), turbiny napędzane powietrzem naporowym RAT (Ram Air Turbine) (energia elektryczna/hydrauliczna) [2].

\section{Projekt wstępny pomocniczej jednostki mocy APU z wyko- rzystaniem ogniwa paliwowego SOFC}

W 2014 r. 25332 samoloty pasażerskie (cargo) należące do 1397 komercyjnych linii lotniczych wykonały ponad 37,4·106 lotów (102 465 lotów dziennie) spalając około $273 \cdot 10^{9}$ litrów $\left(\mathrm{dm}^{3}\right)$ paliwa lotniczego. Dla przykładu: samolot pasażerski Boeing 777-200ER przy masie startowej 242 tony dla pokona- 
nia trasy lotniczej o długości $14260 \mathrm{~km}$ (max. zasięg wersji B 777-200ER) wymaga około $100000 \mathrm{dm}^{3}$ paliwa lotniczego (około $85000 \mathrm{~kg}$ ) Jet A1, zaś zabudowana na pokładzie pomocnicza jednostka mocy APU (Honeywell ‘s 331500 APU) do operacji lotniskowych (m.in. rozruch silników, zasilanie instalacji ECS przy niepracujących sinikach samolotu,) pobiera ok. $1000 \mathrm{dm}^{3}(850 \mathrm{~kg})$ paliwa Jet A1 na jeden lot. W największych lotniczych silnikach tłokowych z okresu II wojny światowej przepływ powietrza nie przekraczał $2 \div 3 \mathrm{~kg} / \mathrm{s}$, a wiele wdrażanych współcześnie silników turboodrzutowych do napędu współczesnych samolotów pasażerskich cechuje zapotrzebowanie powietrza na wlocie (Air Mass Flow) przekraczające $1000 \mathrm{~kg} / \mathrm{s}$.

$\mathrm{W}$ ciągu pięciu pierwszych minut startu i wznoszenia samolotu pasażerskiego z napędem turboodrzutowym, strumień otaczającego powietrza o objętości często przekraczającej $300000 \mathrm{~m}^{3}$ jest przyśpieszany do prędkości osiągającej $300 \mathrm{~m} / \mathrm{s}$, zaś strumień gazów wylotowych o objętości około $75000 \mathrm{~m}^{3}$ jest przyśpieszany do prędkości około $600 \mathrm{~m} / \mathrm{s}$ wytwarzając jednocześnie blisko $3000 \mathrm{~kg} \mathrm{CO}_{2}$ i turbulizując znaczne objętości powietrza w strefie pasów startowych lotnisk i ich przestrzennych przedłużeń.

Konwencjonalna pomocnicza jednostka mocy APU na współczesnym samolocie pasażerskim (np. Honeywell's 331-500 APU - Boeing 777) emituje do atmosfery w czasie jednego lotu (głównie operacje lotniskowe) około $5,3 \mathrm{~kg}$ $\mathrm{NO}_{\mathrm{x}}, 6,2 \mathrm{~kg} \mathrm{CO} 2$ i około 0,4 kg UHCs (niespalone węglowodory). Reasumując, współcześnie lotnictwo emituje około 3\% całej emisji gazów cieplarnianych wytwarzanych na całym świecie, z tendencją wzrostową (około $4 \%$ - 2030), zaś całkowity wpływ lotnictwa na klimat jest trzy - cztery razy większy niż wynika to z samej emisji $\mathrm{CO}_{2}[3,9]$

Uwzględniając fakt dynamicznego wzrostu liczby lotniczych przewozów pasażerskich, ograniczenie emisji gazów cieplarnianych przez lotnictwo pasażerskie należy szukać głównie we wdrażaniu nowych modernizacji istniejących technologii w dziedzinie napędów i systemów pokładowych samolotów pasażerskich poprzez m.in. wprowadzanie do eksploatacji nowoczesnych silników turbowentylatorowych, a także modernizacji wybranych systemów pokładowych samolotów pasażerskich MEA [5].

Modernizacja lotniczych silników turbowentylatorowych mająca na celu m.in. zmniejszenie zużycia paliwa, ograniczenie poziomu generowanego hałasu czy też redukcji emisji $\mathrm{CO}_{2}$ i $\mathrm{NO}_{x}$, realizowana m.in. poprzez wprowadzenie nowych materiałów konstrukcyjnych pozwalających na wzrost temperatury spalin przed turbiną i sprężu, prowadzi do zauważalnego wzrostu emisji $\mathrm{NO}_{\mathrm{x}}$ w gazach wylotowych. Rozwój samolotów pasażerskich MEA, a w okresie naj-

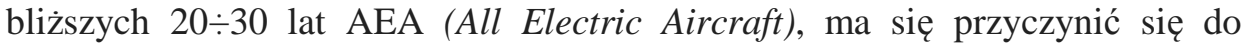
znacznej redukcji emisji $\mathrm{CO}_{2}$ i $\mathrm{NO}_{x}$, a także masy samego samolotu [19].

Nowe samoloty MEA będą bardziej energooszczędne, mające mniejszy wpływ na środowisko i tańsze w eksploatacji. Boeing 787, pierwszy samolot pasażerski zbudowany zgodnie z założeniami MEA, posiada jako pierwszy w tej 
klasie samolotów, rozruszniki elektryczne silników lotniczych. Fakt ten umożliwił znaczną modernizację instalacji pneumatycznej samolotu, eliminując konieczność poboru energii pneumatycznej z APU do rozruchu silników lotniczych $[6,12]$.

Zasadniczy wpływ na stopień zanieczyszczenia powietrza w rejonach portów lotniczych ma czas trwania tzw. operacji lotniskowych, szczególnie związanych z kołowaniem samolotu pasażerskiego tzw. Taxi-out Time. Szacuje się, że tzw. emisja naziemna silników samolotów (APU) w obszarze portu lotniczego (operacje lotniskowe) stanowi ponad $20 \%$ zanieczyszczeń powietrza, wytwarzanych przez współczesne lotnictwo. Zastosowanie rozruszników elektrycznych silników lotniczych zamiast rozruszników pneumatycznych znacznie upraszcza budowę instalacji rozruchu silników lotniczych pozwalając na zastąpienie „konwencjonalnej” wersji APU, pomocniczą jednostką mocy wytwarzającą tylko energię elektryczną np. ogniwem paliwowym. Ogniwo paliwowe (o.p.) jest urządzeniem do elektrochemicznej konwersji energii, w którym następuje przemiana energii chemicznej na energię elektryczną/cieplną przez dwie odseparowane od siebie reakcje elektrochemiczne - reakcję utleniania (paliwo anoda) i redukcji (utleniacz - katoda) [15].

Paliwem dla o.p. najczęściej jest gazowy wodór (doprowadzany w sposób ciągły do elektrody ujemnej - anody), zaś utleniaczem powietrze lub w zastosowaniach specjalnych gazowy tlen (doprowadzany w sposób ciągły do elektrody dodatniej - katody). Teoretycznie, dowolna substancja zdolna do utleniania chemicznego doprowadzana w sposób ciągły do anody, może być używana jako paliwo dla o.p. (Tab. 1) [4]. Ogniwo paliwowe posiada budowę wewnętrzną i cechy zbliżone do baterii galwanicznych, lecz różni się od nich pod wieloma względami:

- akumulator jest urządzeniem magazynującym energię, gdzie maksymalna ilość zgromadzonej energii zależy od ilości reagenta znajdującego się w akumulatorze,

- akumulator przestanie wytwarzać energię elektryczną po zużyciu reagentów (proces rozładowania), zaś do ponownego jego użycia koniecznym jest doprowadzenie energii do akumulatora $\mathrm{z}$ zewnętrznego źródła (proces ładowania),

- ogniwo paliwowe ma możliwość wytwarzania energii elektrycznej w sposób ciągły, o ile paliwo i utleniacz są dostarczane „non stop” do elektrod,

- ogniwo paliwowe zasilane wodorem i tlenem praktycznie nie produkuje żadnych zanieczyszczeń przy bezgłośnej pracy, produktem ubocznym jest woda (para wodna) i w niektórych typach gaz syntezowy,

- ogniwo paliwowe samoczynnie dobiera ilość doprowadzanego paliwa (np. wodór, metan) i reguluje odpowiednią ilość utleniacza (np. tlen).

Zastosowanie ogniwa paliwowego $\mathrm{w}$ pomocniczej jednostce mocy APU pozwoli praktycznie wyeliminować emisję $\mathrm{NO}_{x}$ i ograniczyć emisję $\mathrm{CO}_{2}$ o ponad 50\%, zaś przy wykorzystaniu jako paliwa czystego wodoru lub biopaliw, 
praktycznie o $100 \%$ (Rys. 2). Standardowe ogniwo paliwowe składa się z pojemnika zawierającego elektrody (katoda i anoda) oraz elektrolitu, w którym zanurzona jest półprzepuszczalna membrana/separator [18]. Elektrolit, którego rodzaj określa typ ogniwa, może występować w stanie ciekłym lub stałym, paliwem jest w większości przypadków gazowy wodór (metanol, metan...) zaś utleniaczem, gazowy tlen (powietrze). Podstawą klasyfikacji ogniw paliwowych są dwa zasadnicze kryteria - rodzaj elektrolitu oraz temperatura pracy. W zależności od rodzaju elektrolitu wyróżniamy ogniwa: alkaliczne, polimerowe, $\mathrm{z}$ bezpośrednim utlenianiem metanolu, z kwasem fosforowym, węglanowe, tlenkowo-ceramiczne. W zależności od temperatury pracy wyróżniamy ogniwa:

- o.p. niskotemperaturowe $\left(25 \div 120^{\circ} \mathrm{C}\right)$,

- o.p. średniotemperaturowe $\left(120 \div 500^{\circ} \mathrm{C}\right)$,

- o.p. wysokotemperaturowe $\left(500 \div 1000^{\circ} \mathrm{C}\right)$.

Zaletą ogniw paliwowych jest przeszło dwukrotnie większa sprawność konwersji energii chemicznej na energię elektryczną $(\eta \geq 40 \%)$ w porównaniu do konwencjonalnego układu: silnik turbinowy/generator energii elektrycznej. Podstawowym paliwem dla ogniwa paliwowego jest wodór lub tzw. paliwo wodoronośne (np. $\mathrm{CH}_{4}$ ), co przy wykorzystaniu ogniwa paliwowego jako FC-APU, stwarza konieczność zgromadzenia lub wytworzenia niezbędnych ilości wodoru/paliwa wodoronośnego na pokładzie samolotu pasażerskiego.

Tabela 1. Wybrane parametry fizyko-chemiczne wybranych ogniw paliwowych

Table 1. Selected physico-chemical parameters of selected fuel cells

\begin{tabular}{|c|c|c|c|c|}
\hline Typ ogniwa & Elektrolit & $\begin{array}{c}\text { Temperatura pracy } \\
{\left[{ }^{\mathrm{O}} \mathrm{C}\right]}\end{array}$ & $\begin{array}{c}\text { Sprawność elek- } \\
\text { tryczna [\%] }\end{array}$ & Paliwo \\
\hline $\begin{array}{c}\text { AFC } \\
\text { (Alkaline Fuell Cell) }\end{array}$ & $\begin{array}{l}\text { Roztwór KOH / } \\
\mathrm{NaOH}\end{array}$ & $65 \div 220$ & $30 \div 40$ & $\mathrm{H}_{2}$ \\
\hline $\begin{array}{c}\text { PEMFC } \\
\text { (Polymer Electrolyte } \\
\text { Membrane Fuel Cell) }\end{array}$ & $\begin{array}{c}\text { Polimerowa mem- } \\
\text { brana jonowy- } \\
\text { mienna }\end{array}$ & $65 \div 200$ & $30 \div 45$ & $\mathrm{H}_{2}, \mathrm{CH}_{3} \mathrm{OH}$ \\
\hline $\begin{array}{c}\text { DMFC } \\
\text { (Direct Methanol } \\
\text { Fuel Cell) }\end{array}$ & $\begin{array}{c}\text { Polimerowa mem- } \\
\text { brana jonowy- } \\
\text { mienna }\end{array}$ & $60 \div 120$ & $35 \div 40$ & $\mathrm{CH}_{3} \mathrm{OH}$ \\
\hline $\begin{array}{c}\text { PAFC } \\
\text { (Phosphoric Acid } \\
\text { Fuel Cell) }\end{array}$ & Kwas fosforowy & $200 \div 220$ & $35 \div 40$ & $\mathrm{H}_{2}$ \\
\hline $\begin{array}{c}\text { MCFC } \\
\text { (Molten Carbonate } \\
\text { Fuel Cell) }\end{array}$ & $\begin{array}{c}\text { Stopiony węglan } \\
\text { litu } \\
\text { i potasu }\end{array}$ & $620 \div 650$ & $50 \div 60$ & $\mathrm{H}_{2}, \mathrm{CH}_{4}, \mathrm{CO}$ \\
\hline $\begin{array}{c}\text { SOFC } \\
\text { (Solid Oxide Fuel Cell) }\end{array}$ & $\begin{array}{c}\text { Ceramika tlenkowa } \\
\text { (itr, cyrkon) }\end{array}$ & $800 \div 1000$ & $45 \div 65$ & $\mathrm{H}_{2}, \mathrm{CH}_{4}, \mathrm{CO}$ \\
\hline
\end{tabular}




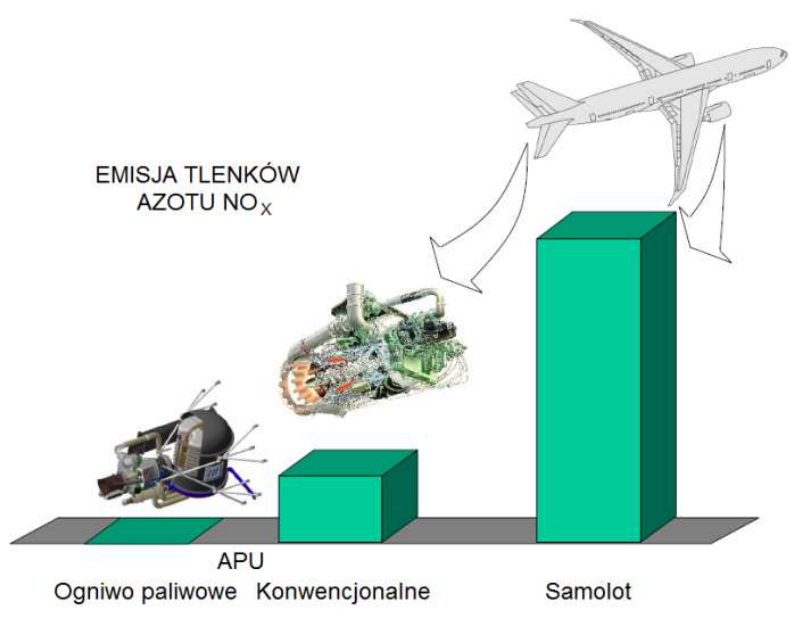

Rys. 2. Porównanie poziomów emisji $\mathrm{NO}_{\mathrm{x}}$ przez silniki samolotu pasażerskiego, silnik APU i ogniwo paliwowe

Fig. 2. Comparison of $\mathrm{NO}_{\mathrm{x}}$ emmision levels from passenger aircraft engines, APU engine and fuel cell

Współcześnie, pod uwagę brane są dwie metody pozyskiwania paliwa dla FC-APU na pokładzie samolotu pasażerskiego:

- zabudowa na pokładzie samolotu zbiorników ciśnieniowych przeznaczonych do przechowywania paliwa wodorowego w postaci płynnej / gazowej,

- Wykorzystanie dla FC-APU ogniw paliwowych, które jako paliwa wymagają paliwa wodoronośnego (np. metan, metanol), możliwego do otrzymania na pokładzie samolotu pasażerskiego $\mathrm{np}$. $\mathrm{z}$ paliwa lotniczego $\mathrm{w}$ procesie reformingu parowego (procesor paliwowy).

Porównując czyste paliwo wodorowe z paliwem lotniczym, można stwierdzić, że zasadniczy problem tkwi w samym paliwie wodorowym, które mimo że zawiera 2.6 razy więcej energii na jednostkę masy niż paliwo lotnicze, to jednak zawiera 4 razy mniej energii na jednostkę objętości niż to samo paliwo (wodór gazowy ma bardzo małą gęstość energetyczną w stosunku do objętości). Aby wodór mógł spełniać rolę paliwa należy go skroplić, schładzając do temperatury $252,8^{\circ} \mathrm{C}$ i utrzymując go $\mathrm{w}$ tym stanie $\mathrm{w}$ specjalnie izolowanych zbiornikach. Zasilanie ogniw paliwowych czystym wodorem (zamiast pokładowego systemu reformingu i odpowiedniej technologii ogniw paliwowych) uprości cały łańcuch procesów wytwarzania paliwa na pokładzie samolotu pasażerskiego, jednakże zastosowanie ,drugiego” paliwa dla systemów energetycznych statku powietrznego wymaga budowy odpowiedniej infrastruktury lotniskowej dla przechowywania i dystrybucji paliwa wodorowego na pokład samolotu. Dodatkowo, jednym z zasadniczych założeń koncepcji MEA oprócz dążenia do minimalizacji liczby różnych systemów energetycznych jest także unikanie wykorzystywania różnych paliw w instalacjach energetycznych samolotu [16, 17]. 
Tym samym można stwierdzić, że najbardziej wskazanym rozwiązaniem jest wykorzystanie paliwa lotniczego, jako paliwa pierwotnego do wytworzenia na pokładzie samolotu pasażerskiego paliwa wodoronośnego (metan, metanol) do zasilania FC-APU. Wodór można wytwarzać z substancji zawierających węgiel, takich jak węglowodory (paliwa lotnicze) lub alkohole za pomocą procesora paliwowego. Procesor paliwowy składa się z reformera (reaktor do reformingu - rzeczywisty etap otrzymywania wodoru) i systemów oczyszczania paliwa wodorowego (głównie ze związków siarki). Skład elementarny dwóch podstawowych paliw lotniczych: benzyny lotniczej i nafty lotniczej jest dość podobny i zawiera: $\mathrm{C}=84 \div 87 \%, \mathrm{H}=13 \div 16 \%$ [7]. Pozyskiwanie paliwa wodorowego dla ogniwa paliwowego na drodze reformingu węglowodorów oparte jest na reformingu parowym oraz częściowym utlenianiu.

Reforming parowy węglowodorów przeprowadza się, przepuszczając mieszaninę par surowca węglowodorowego (np. paliwo lotnicze) i pary wodnej przez np. ceramiczny katalizator wzbogacony niklem. Skład chemiczny paliw lotniczych to tysiące różnych związków i dodatków zawierających śladowe ilości także innych pierwiastków, jednakże z chemicznego punktu widzenia paliwa te składają się głównie (wagowo) z czterech głównych związków chemicznych: heksadekan $\mathrm{C}_{16} \mathrm{H}_{34}(\sim 70 \%)$, toluen $\mathrm{C}_{7} \mathrm{H}_{8}(\sim 15 \%)$, tetralina $\mathrm{C}_{10} \mathrm{H}_{12}(\sim 10 \%)$ i metylonaftalen $\mathrm{C}_{11} \mathrm{H}_{10}(\sim 5 \%)[7,8]$.

Podstawowe reakcje konwersji parowej wyższych węglowodorów parą wodną są reakcjami silnie endotermicznymi, do ich przebiegu konieczne jest dostarczenie energii cieplnej z zewnątrz. W przedziale temperatur $750 \div 1100^{\circ} \mathrm{C}$ wyższe węglowodory są przekształcane bezpośrednio w metan, wodór i węgiel, bez produktów pośrednich według reakcji reformingu parowego [22],

$$
\begin{aligned}
& \mathrm{C}_{n} \mathrm{H}_{m}+n \mathrm{H}_{2} \mathrm{O} \rightarrow(\mathrm{m} / 2+n) \mathrm{H}_{2}+n \mathrm{CO} \\
& \mathrm{CO}+\mathrm{H}_{2} \mathrm{O} \rightarrow \mathrm{CO}_{2}+\mathrm{H}_{2} \\
& \mathrm{CH}_{4}+\mathrm{H}_{2} \mathrm{O} \rightarrow \mathrm{CO}+3 \mathrm{H}_{2}
\end{aligned}
$$

co dla głównych związków składowych paliwa lotniczego, przedstawia się:

$$
\begin{aligned}
& \mathrm{C}_{16} \mathrm{H}_{34}+16 \mathrm{H}_{2} \mathrm{O} \rightarrow 33 \mathrm{H}_{2}+16 \mathrm{CO} \\
& \mathrm{C}_{7} \mathrm{H}_{8}+7 \mathrm{H}_{2} \mathrm{O} \rightarrow 11 \mathrm{H}_{2}+7 \mathrm{CO} \\
& \mathrm{C}_{10} \mathrm{H}_{12}+10 \mathrm{H}_{2} \mathrm{O} \rightarrow 16 \mathrm{H}_{2}+10 \mathrm{CO} \\
& \mathrm{C}_{11} \mathrm{H}_{10}+11 \mathrm{H}_{2} \mathrm{O} \rightarrow 16 \mathrm{H}_{2}+11 \mathrm{CO}
\end{aligned}
$$

Otrzymywany $\mathrm{w}$ procesie reformingu parowego tzw. gaz syntezowy to głównie mieszanina $\mathrm{CO}$ i $\mathrm{H}_{2}\left(\geq 80 \%\right.$ obj.) oraz dodatki: $\mathrm{CO}_{2}, \mathrm{CH}_{4}$ i $\mathrm{H}_{2} \mathrm{O}$. Tlenek węgla stanowi dla większości ogniw paliwowych (oprócz MCFC i SOFC) związek silnie toksyczny, uszkadzający elektrody ogniwa paliwowego, w szczegól- 
ności katalizatory platynowe. Utlenianie tlenku węgla i odseparowanie tak otrzymanego dwutlenku węgla od wyprodukowanego wodoru następuje np. na drodze adsorpcji zmiennociśnieniowej PSA [13, 22]. Częściowe utlenianie węglowodorów przeprowadza się, przepuszczając mieszaninę par surowca węglowodorowego i pary wodnej z niewystarczającą do spalenia ilością tlenu przez np. ceramiczny katalizator. W przedziale temperatur $1250 \div 1600^{\circ} \mathrm{C}$ wyższe węglowodory są przekształcane bezpośrednio w metan, wodór i węgiel, według reakcji częściowego utleniania opisywanych, jako:

$$
\mathrm{C}_{n} \mathrm{H}_{m}+(n / 2) \mathrm{O}_{2} \rightarrow(m / 2) \mathrm{H}_{2}+n \mathrm{CO}
$$

Podstawowe reakcje częściowego utleniania wyższych węglowodorów tlenem są reakcjami silnie egzotermicznymi. Otrzymywany w procesie częściowego utlenienia tzw. gaz syntezowy ma odmienny skład niż w przypadku reformingu parowego, zawiera mniej $\mathrm{H}_{2}$ i $\mathrm{CH}_{4}$ oraz dodatkowo $\mathrm{CO}, \mathrm{CO}_{2}, \mathrm{H}_{2} \mathrm{~S}$, Ar oraz $\mathrm{N}_{2}$. Usunięcie zanieczyszczeń przeprowadza się podobnie jak w przypad$\mathrm{ku}$ reformingu parowego na drodze m.in. adsorpcji zmiennociśnieniowej PSA (Rys. 3).

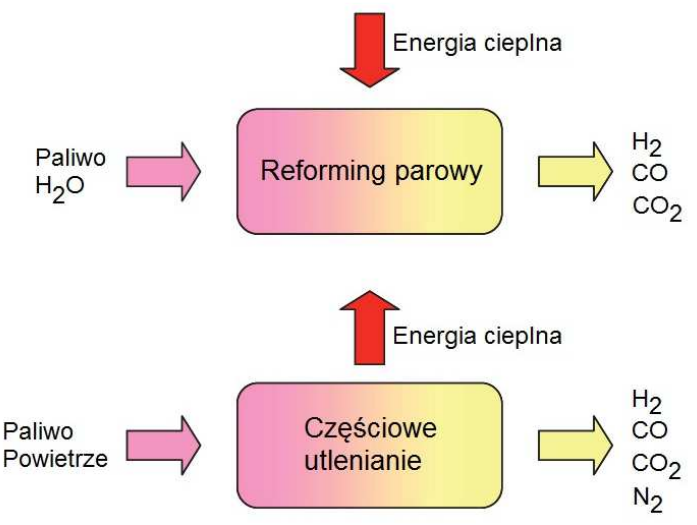

Rys. 3. Porównanie dwóch procesów pozyskiwania wodoru z paliwa lotniczego

Fig. 3. Comparison of two processes of hydrogen generation from aircraft fuel

Dodatkowym zanieczyszczeniem zawartym w gazie syntezowym, bardzo szkodliwym dla pracy ogniw paliwowych, są związki siarki $\left(\mathrm{H}_{2} \mathrm{~S}, \mathrm{COS}\right)$. Komercyjnie dostępne paliwa lotnicze np. Jet A-1 zawierają mniej niż 1000 ppmw (Parts Per Million by Weight) związków siarki, dopuszczalna tolerancja na zawartość związków siarki dla ogniw paliwowych nie przekracza 50 ppmw (PAFC), 1 ppmw (SOFC) czy też 0,1 ppmw (PEMFC) [19, 20]. W ogniwach paliwowych MCFC i SOFC siarka reaguje z niklowym katalizatorem anody, zaś w PEMFC nieodwracalnie uszkadza platynowy katalizator anody, co skutkuje 
szybkim spadkiem wydajności ogniwa przy zawartości związków siarki w paliwie wodoronośnym już powyżej 0,1 ppmw.

Usuwanie związków siarki z gazu syntezowego jest realizowane zazwyczaj w procesie dwuetapowym:

- uwodorowienie COS i innych związków siarki do $\mathrm{H}_{2} \mathrm{~S}$ (katalizator Co-Mo temperatura $80^{\circ} \mathrm{C}$ ),

- usunięcie $\mathrm{H}_{2} \mathrm{~S}$ poprzez zaadsorbowanie $\mathrm{z}$ wykorzystaniem MDEA (2-metylodietanoloamina) - redukcja zawartości siarki do 20 ppmw,

- wysokotemperaturowe usuwanie związków siarki poprzez reakcję z ZnO (temperatura $300^{\circ} \mathrm{C}$ ) - redukcja zawartości siarki poniżej 10 ppmw.

$$
\begin{aligned}
& \mathrm{C}_{2} \mathrm{H}_{5} \mathrm{SH}+\mathrm{H}_{2} \rightarrow \mathrm{C}_{2} \mathrm{H}_{5}+\mathrm{H}_{2} \mathrm{~S} \\
& \mathrm{ZnO}+\mathrm{H}_{2} \mathrm{~S} \rightarrow \mathrm{ZnS}+\mathrm{H}_{2} \mathrm{O}
\end{aligned}
$$

Powyższe procesy stosowane $\mathrm{w}$ systemach naziemnych umożliwiają uzyskanie paliwa wodoronośnego o zawartości wodoru powyżej $98 \%$ przy znikomej zawartości zanieczyszczeń, jednakże stopień złożoności technologicznej, związane z tym rozmiary oraz koszty budowy instalacji, praktycznie eliminują wykorzystanie jej w takiej postaci na pokładzie samolotu pasażerskiego. Modyfikacja procesora paliwowego poprzez eliminację procesu adsorpcji zmiennociśnieniowej PSA umożliwia implementację procesora na pokład samolotu pasażerskiego, kosztem obniżenia jakości paliwa wodoronośnego (obniżone stężenie wodoru, zwiększona zawartość $\mathrm{CO}$ i $\mathrm{CH}_{4}$ ) [5]. Zasadnicze wymagania, jakie musi spełnić ogniwo paliwowe pracujące, jako APU na pokładzie samolotu pasażerskiego, to $[10,14]$ :

- bardzo wysoka niezawodność i bezpieczeństwo, długi czas pracy (> 10000 godzin),

- niska waga, wysoka moc właściwa, mała objętość,

- wysoka tolerancja na cykliczne zmiany temperatury, wstrząsy, wibracje, zmiany położenia przestrzennego, przyspieszenia, itp., a także na zanieczyszczenia paliwa,

- bezawaryjna praca przy wilgotności względnej do $100 \%$, na wysokościach przelotowych $(0 \div 18000 \mathrm{~m})$, gdy temperatura otaczającego powietrza osiąga wartości poniżej $60^{\circ} \mathrm{C}$, a cząstkowe ciśnienie tlenu wynosi jedynie około $20 \%$ wartości na poziomie morza,

- możliwość ciągłej pracy w czasie trwania lotu, celem zapewnienia „dodatkowej energii elektrycznej" dla odbiorników pokładowych przy niesprawności np. jednej z prądnic prądu przemiennego.

Uwzględniając powyższe ograniczenia praktycznie jedynymi typami ogniw paliwowych możliwymi do zastosowania jako APU na pokładach samolotów pasażerskich są o.p.: PEMFC i SOFC. Temperatura pracy ogniwa PEMFC nie przekracza $120^{\circ} \mathrm{C}$, zaś ogniwa $\mathrm{SOFC}$ osiąga wartości prawie 10 krotnie wyższe 
$\left(800 \div 1000^{\circ} \mathrm{C}\right)$. Bardzo wysoka temperatura pracy SOFC w porównaniu z innymi typami ogniw paliwowych, pozwala na wykorzystanie paliwa wodoronośnego „gorszej jakości” zanieczyszczonego tlenkiem węgla i związkami siarki. Wysoka temperatura spalin $\left(750 \div 800^{\circ} \mathrm{C}\right)$ pozwala na dalsze wykorzystanie ciepła reakcji elektrochemicznej (ciepło odpadowe) do reformingu paliwa lotniczego, a także m.in. dla systemów klimatyzacji kabin czy systemów przeciwoblodzeniowych. Dodatkowo spaliny o.p. SOFC mogą być wykorzystane do „napędu” turbiny współpracującej z o.p. SOFC (Hybrid SOFC), która napędzając sprężarkę, umożliwia „sprężenie" rozrzedzonego powietrza zewnętrznego na wysokościach przelotowych na potrzeby zasilania powietrzem o.p.

Zaletami o.p. PEMFC są m.in. niska temperatura pracy, wysoki stopień „rozwoju” technologicznego (w porównaniu z SOFC) a także krótki czas rozruchu, jednakże ogniwa paliwowe tego typu są bardziej „wrażliwe” na zanieczyszczenia paliwa wodoronośnego, głównie przez CO. Ogniwa paliwowe SOFC nie emitują praktycznie żadnych związków $\mathrm{NO}_{\mathrm{x}}$ podczas pracy, a także poprzez zastosowanie stałotlenkowego elektrolitu (nie zawierającego $\mathrm{H}_{2} \mathrm{O}$ ) nie wymagają instalacji nawilżających. Sprawność konwersji energii w o.p. PEMFC nie przekracza $45 \%$, w SOFC pracującym jako samodzielna jednostka powyżej $50 \%$, zaś dla SOFC pracującym w układzie hybrydowym (wraz z turbiną) przekracza $60 \%$.

Minimalny czas uruchomienia turbinowego APU nie powinien przekraczać $45 \div 120$ s (dla poboru energii elektrycznej) oraz $180 \div 360 \mathrm{~s} \mathrm{w}$ przypadku odbioru energii pneumatycznej. Opóźnienie, szczególnie przy poborze energii pneumatycznej, wynika z konieczności „rozgrzania silnika turbinowego APU”, pobór powietrza zza sprężarki APU zwiększa temperaturę gazów wylotowych, co przy „,zimnym” APU grozi „,przegrzaniem” łopatek turbiny silnika turbinowego APU (ograniczenie obciążeń termicznych APU). Zasadniczym problemem w przypadku wykorzystania o.p. jako FC-APU jest bardzo długi, w porównaniu z turbinowym APU, czas rozruchu (Tab. 2) wymagany do osiągnięcia przez o.p. temperatury nominalnej. Badania prowadzone przez firmę Boeing przy projekcie FC-APU SOFC potwierdziły w rozwiązaniach doświadczalnych minimalny czas rozruchu FC-APU dochodzący do 40 minut, co jest zasadniczą wadą tego typu rozwiązań. Czas ten jest stanowczo za długi, podtrzymanie zasilania wybranych odbiorników pokładowych przy awarii źródeł zasadniczych energii elektrycznej na pokładzie współczesnego samolotu pasażerskiego przez akumulatory pokładowe nie przekracza 30 minut, z uwzględnieniem 5 minut na opóźnienie reakcji załogi, czyli czasu od chwili rozpoczęcia wyłączania zbędnych odbiorników energii. Jedynym akceptowalnym rozwiązaniem, wydaje się być praca FC-APU przez cały czas lotu na „tzw. biegu jałowym”, przy minimalnym zużyciu paliwa, pozwalająca osiągać w sytuacji szczególnej moc nominalną w czasie kilkunastu do kilkudziesięciu sekund.

Ogniwo paliwowe SOFC podczas pracy wytwarza energię elektryczną, cieplną i spaliny (gaz syntezowy) zawierające głównie $\mathrm{CO}_{2}$ i $\mathrm{H}_{2} \mathrm{O}$ (Rys. 4). Wy- 
soka temperatura spalin $\left(\mathrm{T}>800^{\circ} \mathrm{C}\right)$ pozwala na wykorzystanie energii cieplnej do napędu turbiny gazowej, połączonej wspólnym napędem ze sprężarką i dodatkowym generatorem/rozrusznikiem.

Tabela 2. Wybrane parametry ogniw paliwowych PEMFC i SOFC

Table 2. Selected parameters of fuels cells PEMFC and SOFC

\begin{tabular}{|l|c|c|}
\hline \multicolumn{1}{|c|}{ Parametr } & PEMFC & SOFC \\
\hline Sprawność o.p. & $35-45 \%$ & $>50 \%$ \\
\hline Temperatura pracy & $<100^{\circ} \mathrm{C}$ & $800 \div 1000^{\circ} \mathrm{C}$ \\
\hline Tolerancja na CO & $\begin{array}{c}\text { Uszkodzenie katalizatora / } \\
\text { Zmniejszenie wydajności }\end{array}$ & Jako paliwo \\
\hline Czas rozruchu & $<5$ min & $>10$ min \\
\hline
\end{tabular}

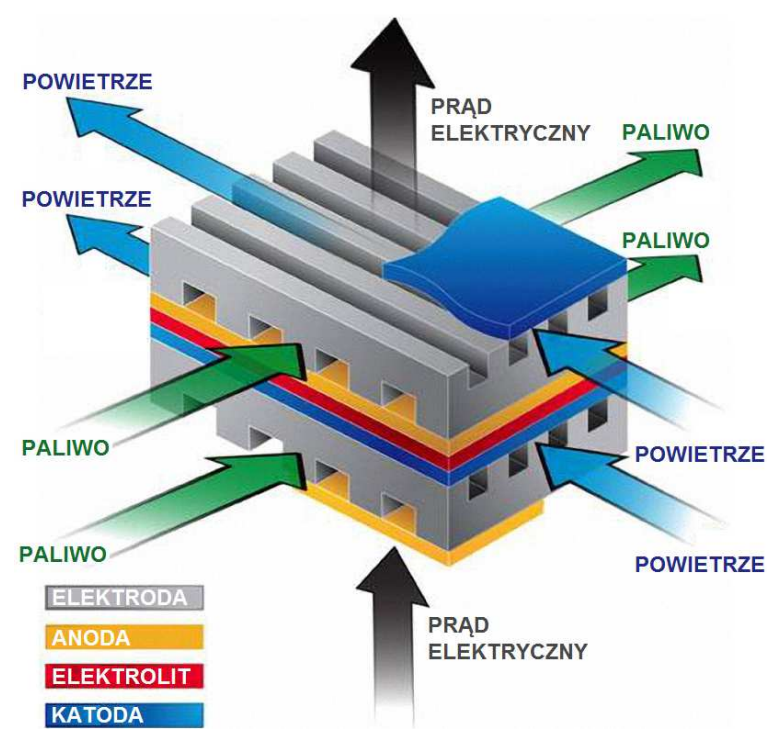

Rys. 4. Uproszczona budowa wewnętrzna płaskiego ogniwa paliwowego SOFC

Fig. 4. Simplified internal structure of flat fuel cell SOFC

Sprężarka współpracująca z o.p. SOFC umożliwia wstępne sprężenie i podwyższenie temperatury powietrza atmosferycznego. Generator wytwarza „dodatkową" energię elektryczną zwiększając ogólną efektywność pracy układu, dodatkowo rozrusznik „rozkręcając” sprężarkę przy niepracującej turbinie, przyśpiesza rozruch o.p. (Rys. 5). Moc elektryczna generowana przez APU na pokładzie współczesnego samolotu pasażerskiego zgodnie z normą MIL-STD-

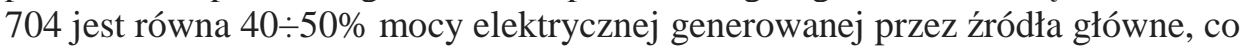
dla FC-APU projektowanego dla samolotu klasy Boeing 787 określa generowaną moc elektryczną na poziomie $450 \div 500 \mathrm{~kW}$ [20]. 


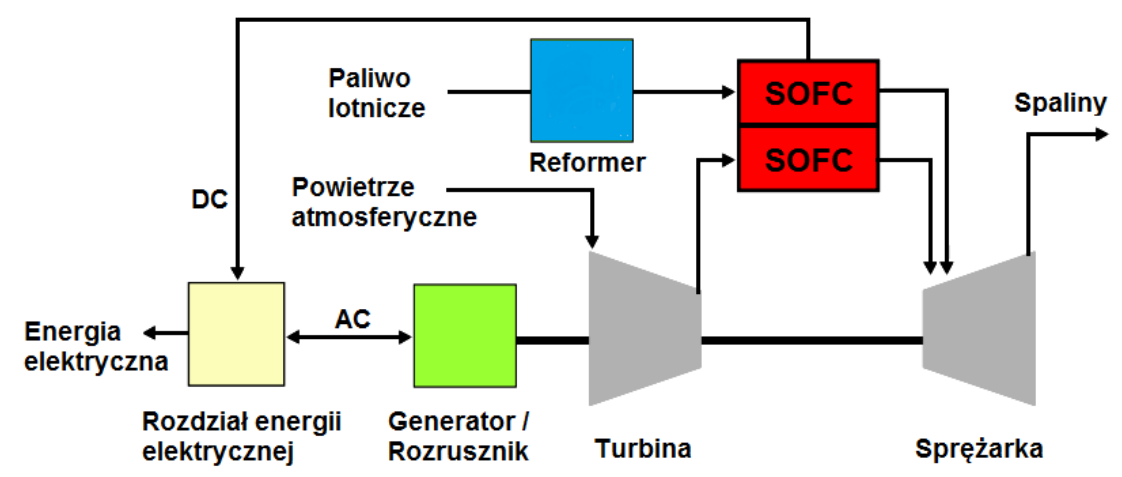

Rys. 5. Uproszczony schemat funkcjonalny o.p. SOFC pracującego w układzie hybrydowym

Fig. 5. Simplified functional diagram of o.p. SOFC operated in the hybrid system

Schemat funkcjonalny proponowanego systemu hybrydowego FC-APU przedstawiono na rysunku 6. Powietrze dla FC-APU pobierane $\mathrm{z}$ atmosfery, jest wstępnie sprężane przez sprężarkę, a następnie doprowadzane do rekuperatora (wymiennika ciepła). Wymiennik ciepła „zasilany niewykorzystanym” gorącym powietrzem z o.p. (temp. $800 \div 850^{\circ} \mathrm{C}$ ) zwiększa temperaturę powietrza na wlocie do o.p. do wartości dochodzącej do $600 \div 700^{\circ} \mathrm{C}$, co pozwala na zwiększenie efektywności pracy oraz uniknięcia naprężeń termicznych o.p.

Gorące powietrze z wyjścia o.p. po przejściu przez rekuperator doprowadzane jest do komory dopalania, gdzie także doprowadzane jest ,niewykorzystane" paliwo z wyjścia o.p. wraz ze spalinami (głównie $\mathrm{CO}$ i $\mathrm{H}_{2} \mathrm{O}$ ) po przejściu przez skraplacz (odzyskiwanie $\mathrm{H}_{2} \mathrm{O}$ ). W komorze dopalania następuje katalityczne dopalanie węgla zawartego w $\mathrm{CO}$, w efekcie czego temperatura otrzymanych spalin (głównie $\mathrm{CO}_{2}$ ) wzrasta do $1100 \div 1200^{\circ} \mathrm{C}$, które następnie podgrzewają reformer (reforming parowy) i podgrzewacz paliwa doprowadzanego do reformera (paliwo przekształcane do postaci gazowej) i kierowane na łopatki turbiny, która poprzez wspólny wał napędowy napędza sprężarkę oraz generator / rozrusznik. Dodatkowo do reformera doprowadzana jest woda, przekształcana w parę w podgrzewaczu paliwa (reforming parowy) [21, 23]. Zakładając, że w systemie hybrydowym FC-APU [10, 13]:

- zachodzi adiabatyczna wymiana ciepła przez bezstratne wymienniki ciepła,

- sprężarka i turbina są elementami bezstratnymi,

- paliwem jest n-dodekan $\left(\mathrm{C}_{12} \mathrm{H}_{26}\right)$ - skład zbliżony do paliwa Jet-A,

- temperatura o.p. jest stała. 


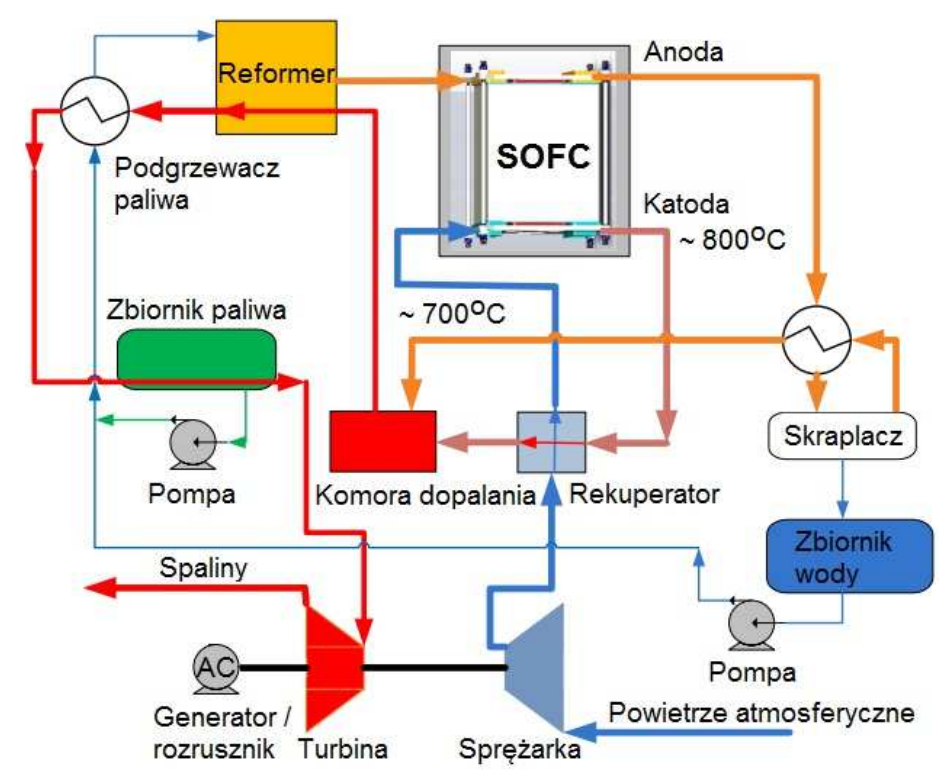

Rys. 6. Schemat funkcjonalny proponowanego systemu hybrydowego FC-APU (rysunek własny na podstawie [22])

Fig. 6. Functional diagram of the proposed hybrid system FC_APU (own figure prepared on the basis of [22])

Siłę elektromotoryczną ogniwa $E_{r}$ można obliczyć z równania Nernsta:

$$
E_{r}=E_{0}+\Delta E=\frac{-\Delta G_{0}}{n F}+\frac{R T}{n F} \ln \frac{p_{\mathrm{H}_{2}}+p_{\mathrm{O}_{2}}^{1 / 2}}{p_{\mathrm{H}_{2} \mathrm{O}}}
$$

gdzie: $E_{r}$ - napięcie obwodu otwartego

$E_{0}$ - siła elektromotoryczna (przy stałym ciśnieniu)

$E$ - napięcie o.p.

$n$ - liczba elektronów przenoszonych pomiędzy elektrodami na mol reagenta

$T$ - temperatura pracy ogniwa

$p_{\mathrm{H} 2}, p_{\mathrm{O} 2}, p_{\mathrm{H} 2 \mathrm{O}}$ - ciśnienia paliwa (np. wodoru), tlenu i wody

$F$ - stała Faradaya $\rightarrow 9,648 \cdot 10^{4}$

$G_{0}$ - funkcja Gibbsa (entalpia swobodna)

Uwzględniając nieodwracalne straty w o.p. rzeczywiste napięcie wyjściowe $U_{0}$ :

$$
U_{O}=E_{r}-\left(V_{\text {Activation }}+V_{\text {Ohmic }}+V_{\text {Concentration }}\right)
$$


- $V_{\text {Activation }} \rightarrow V_{\text {Activation }}=\frac{R T}{n \alpha F} \ln \left[\frac{i+i_{n}}{i_{O}}\right] \rightarrow$ polaryzacja aktywacyjna

- $V_{\text {Ohmic }} \rightarrow V_{\text {Ohmic }}=r\left(i+i_{n}\right) \rightarrow$ polaryzacja omowa

- $V_{\text {Concentration }} \rightarrow V_{\text {Concentration }}=-\frac{R T}{n F} \ln \left[1-\frac{i+i_{n}}{i_{L}}\right] \rightarrow$ polaryzacja stężeniowa

gdzie: $\alpha$ - bezwymiarowy współczynnik określający parametry ładowania transportu ładunków w o.p.) - określony empirycznie,

$i$ - gęstość prądu,

$i_{n}$ - gęstość prądu granicznego,

$i_{L}$ - maksymalna gęstość prądu,

$i_{O}$ - gęstość prądu wymiany,

$r$ - rezystywność powierzchniowa.

Przyrost temperatury powietrza $\Delta \mathrm{T}_{\mathrm{S}}$ na sprężarce:

$$
\Delta T_{S}=\frac{T_{i n S}\left(p_{S}^{\frac{(\gamma-1)}{\gamma}}-1\right)}{\eta}
$$

gdzie: $T_{i n S}$ - temperatura powietrza na wlocie do sprężarki (zewnętrznego)

$P_{S}$ - spręż sprężarki

$\gamma$ - wykładnik izentropy powietrza

$\eta$ - sprawność

Moc sprężarki $\mathrm{P}_{\mathrm{S}}$ jest określona zależnością:

$$
P_{S}=C_{P} \Delta T_{S} m_{P}
$$

gdzie: $C_{P}$ - ciepło właściwe powietrza

$$
m_{P} \text { - masa powietrza }
$$

Spadek temperatury $\Delta \mathrm{T}_{\mathrm{T}}$ na turbinie:

$$
\Delta T_{T}=T_{i n T}\left(1-p_{T}^{\frac{(1-2)}{\gamma}}\right) \eta
$$

gdzie: $T_{i n T}$ - temperatura powietrza na wlocie do turbiny $p_{T}$ - współczynnik ekspansji na turbinie

Moc turbiny $\mathrm{P}_{\mathrm{T}}$ jest określona zależnością:

$$
P_{T}=C_{P} \Delta T_{T} m_{T}
$$

gdzie: $M_{T}$ - masa gazów wylotowych. 
Moc wyjściowa generatora $\mathrm{P}_{\mathrm{E}}$ współpracującego z turbiną

$$
P_{E}=\left(P_{T}-P_{S}\right) \eta_{E}
$$

gdzie: $\eta_{E}$ - sprawność generatora

Całkowita moc wyjściowa (elektryczna) $\mathrm{P}_{\mathrm{TE}}$

$$
P_{T E}=P_{F C}+P_{E}
$$

gdzie: $P_{F C}$ - moc ogniwa paliwowego.

Pojedyncze o.p. SOFC wytwarza prąd stały o napięciu $U_{O}=0,7 \div 0,85 \mathrm{~V}$ i natężeniu proporcjonalnym do powierzchni czynnej elektrod. Celem uzyskania wymaganego napięcia i mocy wyjściowej stosu o.p. pojedyncze o.p. łączone są szeregowo/równolegle. Szybkość dopływu paliwa i utleniacza do o.p. jest determinowana głównie przez pobór mocy elektrycznej przez odbiorniki pokładowe. Dla paliwa (wodór) i utleniacza (powietrze) faktyczne zapotrzebowanie przez o.p. SOFC jest określone:

$$
\begin{aligned}
& m_{H_{2}}=1,05 \cdot 10^{-8} \cdot\left(\frac{P_{F C}}{U_{O}}\right) \\
& m_{\text {powietrze }}=3,57 \cdot 10^{-7} \cdot\left(\frac{P_{F C}}{U_{O}}\right)
\end{aligned}
$$

Efektem ubocznym pracy o.p. jest m.in. woda (para wodna). Produkcja wody podczas pracy ogniwa paliwowego jest określona równaniem:

$$
m_{H_{2} O}=9,34 \cdot 10^{-8} \cdot\left(\frac{P_{F C}}{U_{O}}\right)
$$

Sprawność konwencjonalnego APU w warunkach naziemnych osiąga $15 \div 20 \%$, sprawność hybrydowego o.p. SOFC przekracza $60 \%$, tym samym można założyć, że hybrydowe o.p. o zbliżonej elektrycznej mocy wyjściowej zużyje tylko około $25 \%$ paliwa dla konwencjonalnego APU dając $75 \%$ oszczędności zużycia paliwa. Sprawność konwencjonalnego APU w czasie lotu wzrasta do $40 \div 45 \%$, sprawność hybrydowego o.p. SOFC wzrasta do około $70 \div 75 \%$, tym samym można uzyskać $40 \%$ oszczędności zużycia paliwa przez APU. Odpowiada to oszczędności około $340 \cdot 10^{3} \mathrm{~kg}$ paliwa rocznie dla samolotu Boeing 777 lub około $1360 \cdot 10^{3} \mathrm{~kg}$ paliwa rocznie dla samolotu Boeing 737. 


\section{Podsumowanie}

W artykule przedstawiono koncepcję wykorzystania ogniwa paliwowego jako pomocniczej jednostki mocy dla współczesnego samolotu pasażerskiego zbudowanego zgodnie z założeniami MEA. Projekt wstępny FC-APU wykorzystuje wysokotemperaturowe ogniwo paliwowe SOFC współpracujące z turbiną napędową w układzie hybrydowym o sprawności konwersji energii $60 \div 70 \%$. Dodatkowym atutem ogniwa paliwowego SOFC jest możliwość zasilania paliwem wodoronośnym pozyskiwanym $\mathrm{z}$ paliwa lotniczego w procesie reformingu. $3 \div 4$ krotny wzrost sprawności konwersji energii przez FC-APU w porównaniu z konwencjonalnym turbinowym APU doprowadzi do zmniejszenia o trzy czwarte ilości paliwa pobieranego przez APU. Dodatkowo wykorzystując fakt, że FC-APU wytwarza energię elektryczną wykorzystując procesy elektrochemiczne, a nie poprzez spalanie, znacznemu ograniczeniu ulegnie emisja tlenków azotu, siarki oraz węgla. Zastąpienie konwencjonalnego APU ogniwem paliwowym SOFC wymaga nie tylko modernizacji części ogonowej płatowca, a także wybranych systemów energetycznych samolotu pasażerskiego (Rys. 7).

Produktem ubocznym pracy FC-APU jest woda, która po odpowiedniej filtracji może zostać wykorzystana do celów higienicznych na pokładzie samolotu. Zasadniczą wadą FC-APU jest wysoka złożoność konstrukcji w porównaniu z konwencjonalnym APU, a także bardzo długi, w odniesieniu do obowiązujących norm, czas rozruchu FC-APU. Technologia FC-APU SOFC ma zastąpić konwencjonalne APU, ale szereg problemów technologicznych (m.in. kompaktowa budowa reformera, efektywne metody odsiarczania paliwa wodorowego, a także problemy związane z izolacją termiczną ze względu na wysoką temperaturę pracy) powoduje, że jest mało prawdopodobne, iż pierwsze FC-APU pojawią się na pokładach współczesnych samolotów pasażerskich przed 2020 rokiem.

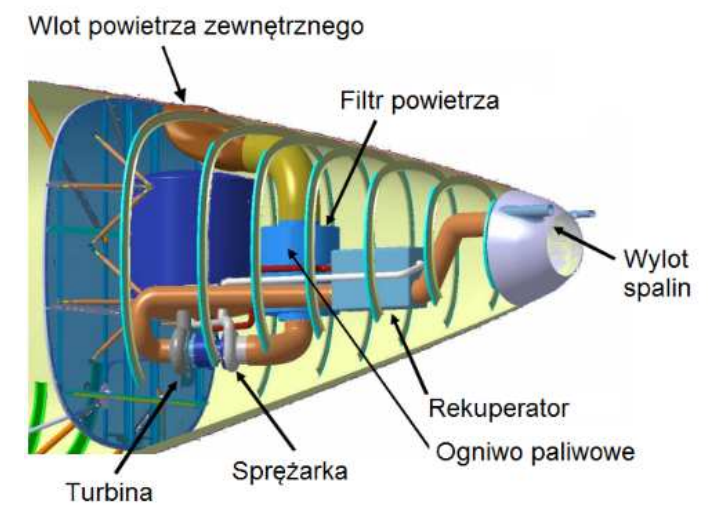

Rys. 7. Przykładowy schemat zabudowy FC-APU w części ogonowej płatowca współczesnego samolotu pasażerskiego (wg [13])

Fig. 7. Exemplary scheme of FC-APU structure located in tail part of airframe of modern passenger aircraft (according to [13]) 


\section{Literatura}

[1] Abdel-Fadil R. et al.: Electrical distribution power systems of modern civil aircrafts, 2nd Int. Conf. Energy Systems and Technologies, Cairo 2013.

[2] Abdel-Hafez A.: Power generation and distribution system for a more electric aircraft - A review, Recent Advances in Aircraft Technology 2012, Ramesh Agar-wal (ed.), InTech, DOI: 10.5772/37290.

[3] Adamowicz M. i inni.: Elektryczne instalacje pokładowe, Wydawnictwo Politechniki Warszawskiej, Warszawa 1986.

[4] Bradley T. H.: Modeling, Design and energy management of fuel cell systems for aircraft, PhD dissertation, Georgia Institute of Technology 2008.

[5] Chick L.: Assessment of solid oxide fuel cell power system for greener commercial aircraft, Pacific Northwest National Laboratory 2011.

[6] Commercial aircraft propulsion and energy systems research: reducing global carbon emissions, The National Academies Press, Washington 2016.

[7] Demusiak G.: Otrzymywanie paliwa wodorowego metodą reformowania gazu ziemnego dla ogniw paliwowych małej mocy, Instytut Nafty i Gazu, Warszawa 2012.

[8] Dzieranowski P. i inni: Turbinowe silniki odrzutowe, WKiŁ, Warszawa 1983.

[9] Eismin T.: Aircraft Electricity and Electronics McGraw-Hill Professional 2014

[10]Mackay A., Hill J.: Modelling of fuel cell APU utilization for aircraft applications, 46th AIAA Joint Propulsion Conf. \& Exhibit, Nashville 2010.

[11]Moir I., Scabridge A.: Aircraft systems: Mechanical, Electrical, and Avionics Subsystems Integration, Third Edition Wiley \& Sons, Ltd. 2008.

[12]Norma obronna NO-15-A200, Warszawa 1998.

[13]Rajashekara K.: Hybrid fuel cell power in aircraft, IEEE Explore Document 2008.

[14]Rajashekara K.: Solid oxide fuel cell/gas turbine hybrid APU system for aerospace applications, IEEE Explore Document 2006.

[15]Scholz D.: An optimal APU for passenger aircraft, 5th CEAS Air and Space Conf., Delft 2015.

[16]Spitzer C.R.: The Avionics Handbook CRC PRESS LLC, Washington 2001.

[17]Stefanowicz A.: Pokładowe układy pomiarowe, Wydawnictwo Politechniki Warszawskiej, Warszawa 1984.

[18]Steinberger-Wilckens R., Lehnert W.: Innovations in fuel cell technologies, RSC Publishing 2010.

[19]Szczeciński S. i inni: Lotnicze zespoły napędowe cz. 1, WAT, Warszawa 2009.

[20]Tareq S.: SOFC auxiliary power units (APUs) for vehicles TRRF05, Fuel Cell technology, Lund 2008.

[21]Tooley M.: Aircraft electrical and electronic systems, Elsevier 2009.

[22]Whyatt G., Chick L.: Electrical generation for more-electric aircraft using solid oxide, Fuel Cells Pacific Northwest National Laboratory 2012.

[23]Zizelman J. et al.: Solid oxide fuel cell auxiliary power unit, SAE World Congress, Detroit 2002. 


\section{ANALYSIS OF THE POSSIBILITY OF USE OF A SOLID OXIDE FUEL CELL AS A AUXILIARY POWER UNIT FOR MODERN PASSENGER AIRCRAFT}

\section{S u m m a r y}

Modern passenger aircrafts belongs to the one of the most reliable and safe means of public transport. These aircrafts are certified according to ETOPS (Extended-range Twin-engine Operational Performance Standards) and they enable the introduction of twin-engine passenger aircraft on transcontinental routes which were earlier unavailable for twin-engine aircrafts. ETOPS standard requires the use aboard of the twin-engine passenger aircraft additional emergency sources of electrical, pneumatic and hydraulic power which partly compensate a decrease in performance on-board power systems at the failure of one of the engines and systems associated with them. The article describes an analysis of the use of different types of fuel cells in the aerospace engineering and presents preliminary design of the auxiliary power unit APU using fuel cell SOFC (Solid Oxide Fuel Cell), intended for emergency power supply of passenger aircraft in the concept of "More Electric Aircraft".

Keywords: passenger aircraft, auxiliary power unit, More Electric Aircraft, fuel cell, SOFC Solid Oxide Fuel Cell

DOI: $10.7862 / \mathrm{rm} .2017 .04$

Otrzymano/received: 11.12 .2016

Zaakceptowano/accepted: 14.02.2017 